DOI: https://doi.org/10.31933/dijdbm.v2i1 Received: $23^{\text {th }}$ October 2020, Revised: $15^{\text {th }}$ November 2020, Publish: $10^{\text {th }}$ December 2020

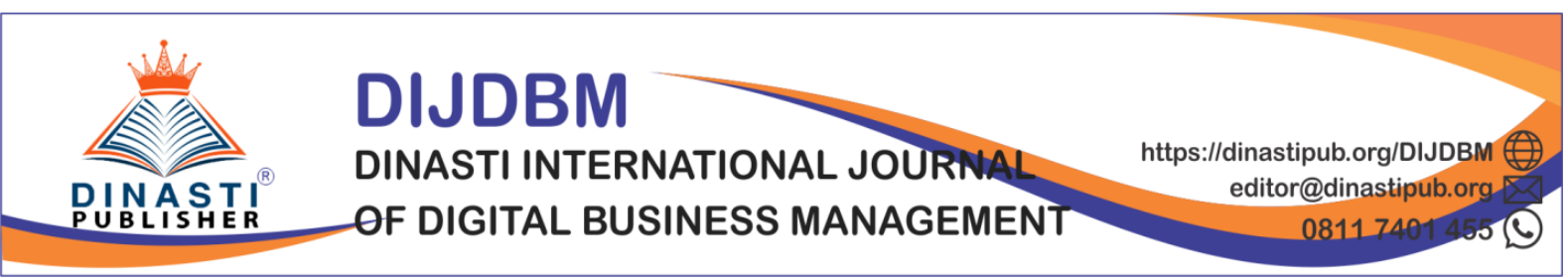

\title{
INFLUENCE OF SERVICE QUALITY AND SCHOOL IMAGE ON SATISFACTION AND ITS IMPLICATIONS TOWARDS LOYALTY OF STUDENTS SMK PGRI 35 JAKARTA
}

\author{
Muhamad Rusdi ${ }^{1}$, Mochamad Mukti Ali ${ }^{2}$ \\ ${ }^{1,}$ Mercu Buana,University Indonesia. Email: rusdi359679@gmail.com \\ ${ }^{2}$ Mercu Buana University, Indonesia. \\ Corresponding Author: First Author ${ }^{1}$
}

\begin{abstract}
The purpose of this study was to determine the effect of service quality, school image on the satisfaction and loyalty of students of SMK PGRI 35 Jakarta. The population used in this study were students of SMK PGRI 35 Jakarta with a total sample of 160 respondents. Data were collected through a questionnaire using a Likert scale. The data analysis of this research used SEM with Lisrel. The research results show that service quality and school image have a positive and significant effect on satisfaction and loyalty, and satisfaction has a positive and significant effect on loyalty. In addition, the results of this research indicate that without going through the intervening variables, it will directly have a higher effect value than indirectly.
\end{abstract}

Keywords: Service Quality, School Image, Satisfaction, Loyalty.

\section{INTRODUCTION}

Education plays a very important role in the progress of civilization. Education is an effort so that humans can improve and develop their potential through a learning process and / or other methods that are known and recognized by the community. There is no other way to improve the quality of a nation except through improving the quality of its education. The function of education in Indonesia is to develop capabilities and shape the character and civilization of the nation with dignity in the framework of educating the nation's life. Whereas the purpose of education is to develop the potential of students to become human beings who believe and fear God Almighty, have noble character, are healthy, knowledgeable, competent, creative, independent, and become democratic and responsible citizens. One of the ways to achieve this goal is the government to organize vocational secondary education.

Vocational secondary education is education at the secondary education level that prioritizes the development of the ability of students to carry out certain types of work. Vocational High School (SMK) organizes educational programs tailored to the types of employment (PP No.29 of 1990). SMK has many skill programs. The expertise program carried out at SMK adapts to the needs of the existing work world. Expertise programs at the 
SMK level also adjust to community and market demands. The SMK curriculum is made so that students are ready to immediately work in the world of work. The content of the existing curriculum in SMK is arranged in such a way as to suit the needs of the existing work world and aims so that students do not experience significant difficulties when entering the real world of work.

DKI Jakarta is one of the most populous cities in Indonesia which has a very large population of productive age at the junior high school level and will later continue to SMA/SMK/MAK. The interest of junior high school graduates who continue to vocational high schools in DKI Jakarta has experienced a decline in the 2014-2015 school year, but has continued to increase in the last three years. Until now, the number of state SMKs in DKI Jakarta is 63 schools, which is very different from private SMKs, which are 516 schools. So that the competition in private SMK is very much. The small number of State Vocational Schools in Jakarta causes the number of students accepted at State Vocational High Schools is very limited. The following is a statistical comparison of the number of private vocational school students in DKI Jakarta, Region I, West Jakarta Administrative City, Cengkareng District, and SMK PGRI 35 in the last 5 years. It can be seen in Figure 1 below:

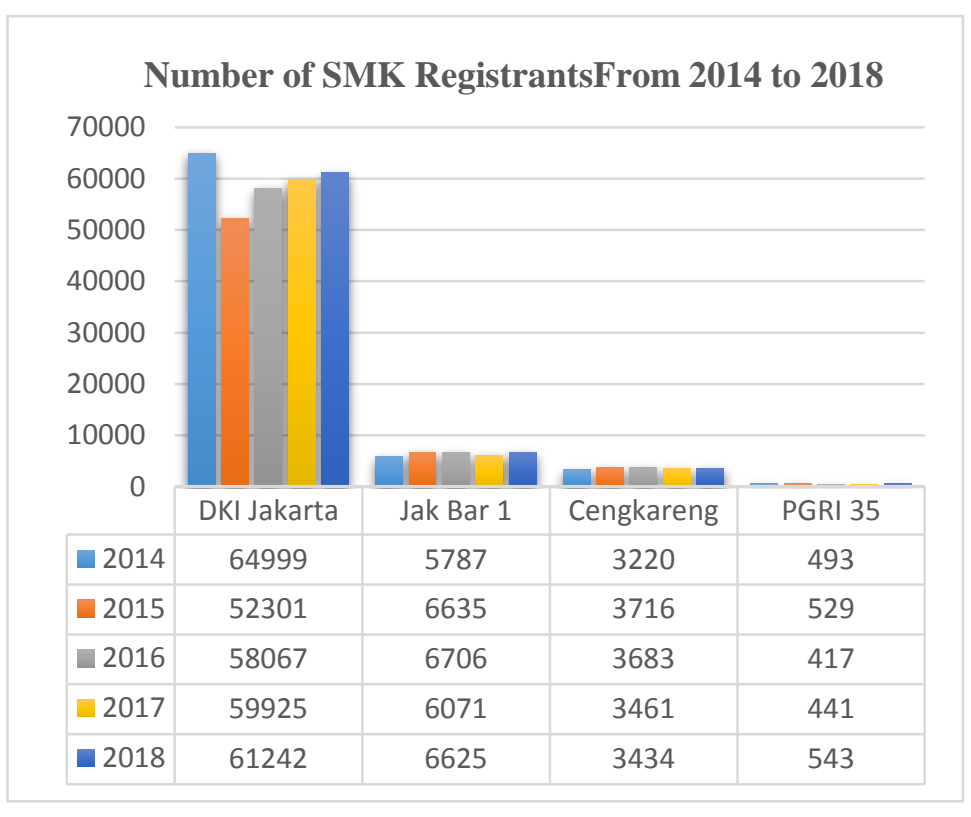

Fig 1. Number of SMK Registrants From 2014 to 2018

Figure 1. above shows the number of new vocational student registrants for SMK from 2014 to 2018. From Figure 1. It is also seen both from the Provincial, Municipal, District, and SMK PGRI levels over the last 5 (five) years experiencing fluctuation with details in the table 1. the following:

Table 1. Number of New Students of SMK DKI Jakarta

\begin{tabular}{lcrrrrr}
\hline \multirow{2}{*}{ No } & \multirow{2}{*}{ School } & \multicolumn{5}{c}{ Years } \\
\cline { 3 - 7 } & & 2014 & 2015 & 2016 & 2017 & 2018 \\
\hline 1 & SMK Negeri & 15.854 & 14.611 & 15.106 & 15.228 & 16.560
\end{tabular}




\begin{tabular}{|c|c|c|c|c|c|c|}
\hline 2 & SMK Swasta & 64.999 & 52.301 & 58.067 & 59.925 & 61.242 \\
\hline & Total & 80.853 & 66.912 & 73.173 & 75.153 & 77.802 \\
\hline
\end{tabular}

From table 1. it can be seen that the number of students of SMK Negeri in the last four years has continued to increase. This data shows that the number of students at State Vocational Schools in Jakarta tends to increase from year to year. The limited number of students admitted to State Vocational High Schools has made private SMKs compete to accept new students. DKI Jakarta is divided into 5 Administrative City Regions, namely the Administrative City of Central Jakarta, East Jakarta, South Jakarta, West Jakarta, and North Jakarta along with the Thousand Islands. Each Administrative City is divided into region 1 and region 2. West Jakarta Region 1 Administrative City consists of 3 districts, namely Cengkareng, Kali Deres, and Tambora. In Cengkareng sub-district there are 24 SMK, consisting of 2 State Vocational Schools and 22 Private Vocational Schools. The data for new students in Cengkareng District can be seen in table 2.The following:

Tabel 2. Number of New Students of SMK in Cengkareng

\begin{tabular}{|c|c|c|c|c|c|c|}
\hline \multirow{2}{*}{ No } & \multirow{2}{*}{ School } & \multicolumn{5}{|c|}{ Years } \\
\hline & & 2014 & 2015 & 2016 & 2017 & 2018 \\
\hline 1 & SMK Negeri & 536 & 532 & 543 & 599 & 672 \\
\hline \multirow[t]{2}{*}{2} & SMK Swasta & 3.220 & 3.716 & 3.683 & 3.461 & 3.434 \\
\hline & Total & 3.756 & 4.248 & 4.226 & 4.060 & 4.106 \\
\hline
\end{tabular}

Based on table 1.3, the number of students of SMK Negeri in Cengkareng District in 2015 had experienced a slight decrease of $1 \%$. But after that the number has continued to increase in the last three years. In 2016 it increased 2\%, in 2017 it increased by 10\%, and in 2018 it increased by $12 \%$. This shows that there is an increase in the quota of new students being opened for State Vocational High Schools, either adding study groups or opening new majors.

SMK PGRI 35 is one of the private vocational schools for the Business and Management group located in the Cengkareng District SMK PGRI 35 which has 3 Skills Competencies, namely Accounting, Office Administration, and Marketing. SMK PGRI 35 was founded in 1999, and is one of the private SMKs which has the fourth largest number of students out of the twenty-two private SMKs in Cengkareng District. The data can be seen as follows:

Table 3. Number of New Students of SMK PGRI 35

\begin{tabular}{lcccccc}
\hline & & \multicolumn{5}{c}{ Years } \\
\cline { 3 - 7 } No & Dept. & 2014 & 2015 & 2016 & 2017 & 2018 \\
\hline \multirow{2}{*}{1} & Accounting & 170 & 205 & 169 & 182 & 210
\end{tabular}




\begin{tabular}{lllllll}
2 & Office Adm. & 163 & 164 & 128 & 132 & 170 \\
3 & Marketing & 160 & 160 & 120 & 127 & 163 \\
\hline & Total & 493 & 529 & 417 & 441 & 543 \\
\hline & Source : Tata usaha SMK PGRI 35 & & &
\end{tabular}

It can be seen from table 3 above that the number of new student registrants at SMK PGRI 35 has fluctuated over the last five years, both majoring in Accounting, Office Administration, and Marketing. In 2015 the Accounting Department increased by 21\%, Office Administration increased by 1\%, and Marketing remained. In 2016 all majors experienced a decline, majoring in Accounting fell 18\%, Office Administration fell 22\%, and Marketing fell 25\%. In 2017 experienced, the Department of Accounting rose 8\%, Office Administration increased 3\%, and Marketing increased 6\%. Meanwhile, in 2018 there was another increase, the Accounting Department increased by $15 \%$, Office Administration increased by $29 \%$, and Marketing increased by $28 \%$.

The phenomenon that occurs is the increase in the number of new student registrants at SMK PGRI 35 in the last three years. Registrants at SMK PGRI 35 in 2017 experienced an increase of $6 \%$, whereas at the same time students of private vocational schools in Cengkareng District were generally experiencing 6\%. In 2018 the registrants at SMK PGRI 35 again experienced a significant increase, namely from 441 to 543 or an increase of 23\%, even though at the same time students of private vocational schools in Cengkareng District had a decline again by $1 \%$. Departing from the phenomenon that occurred then a preliminary survey was carried out related to service quality, school image, service quality and student loyalty, the results of the preliminary survey showed that $90 \%$ or 54 students expressed satisfaction and $10 \%, 40 \%$ of students stated that satisfaction was very influenced by service quality, $85 \%$ or 51 students stated that graduates of SMK PGRI 35 were competent, $85 \%$ or 51 students stated that they were willing to recommend SMK PGRI 35 to others so that this research will focus on further how much influence the quality of service and image of the school on satisfaction and the implications for the loyalty of students at SMK PGRI 35 Jakarta

\section{LITERATURE REVIEW}

Service Quality.

Quality consists of several factors that can meet consumer expectations. The concept of quality is considered a measure of the perfection of a product or service which consists of design quality and conformity quality (Tjiptono \& Chandra, 2016). Service quality is much more difficult to define, define and measure when compared to the quality of goods. Lewis \& Booms in Tjiptono \& Chandra (2016) suggests that service quality is a measure of how well the level of service provided is able to materialize according to customer expectations. Tjiptono \& Chandra (2016) also stated that the quality of service itself is found by the company's ability to meet customer needs and desires in accordance with customer expectations. Syamsiah (2011) also suggests that the relationship between service quality and perceived value is that quality service will increase value for customers so that it can create satisfaction which in turn can increase customer loyalty. Studies on service quality on satisfaction in education have also been carried out, namely Rinala et al. (2013) Radja et al (2013), Khusaeni (2016), Wantara (2015), Lunarindiah (2016), Chandra, et al (2018), Miss (2014), Haruna, et al 2016), Martines, et al ( 2016), Subrahmanyam (2016), Usman et al (2016), Mestrovic et al (2017), Shahsavar, et al (2017), Rahman, et al (2017), and Chandra et al (2018) who suggest that service quality positive and significant effect on student or student 
satisfaction. While other research related to student satisfaction and loyalty has also been carried out, including research conducted by Rinala et al (2013), Mulyana et al (2015), Husaeni (2016), Chandra et al (2018), Usman et al ( 2016), Zhang et al (2016), Shahsavar (2017) who state that satisfaction affects loyalty.

\section{School Image.}

Image is a set of beliefs, ideas and impressions that a person has about an object (Kotler \& Keller, 2012). Meanwhile, Rulsan (2012) states that the image itself is abstract and cannot be measured mathematically, but its form can be felt from the results of good or bad assessments. Image is formed from how the institution carries out operational activities which have the main foundation in terms of services (Buchori, 2014). Fahrurrozi (2012) states that there are many factors that influence the formation of the image of an educational institution, including academic reputation, school appearance, costs, personal attention, location, career placement, social activities, and study programs. According to Shirley Harrison in Suwandi (2011) the image of an organization consists of: (1) Personality, (2) Reputation, (3) Value, (4) Corporate Identity. A number of studies have been carried out regarding the image of schools on satisfaction and loyalty, including research conducted by Mulyana et al (2015), Husaeni (2016), Lunarindiah (2016), Azoury et al (2014), Shahsavar et al (2017), Kunanusorn et al (2015) whose research results indicate that the image of an organization has a positive and significant effect on the satisfaction variable. Meanwhile, other research conducted by Ali et al (2014), Mulyana et al (2015), Khusaeni (2016), Usman et al (2016) suggests that the image of an institution or institution has a provide a positive and significant influence on the loyalty variable.

\section{Satisfaction.}

For a company or educational institution such as a school that is centered on customers or students, customer or student satisfaction is the goal of the company or educational institution. Increasing competitors require companies or schools to have a strategy to compete, survive and develop. According to Kotler (2012) satisfaction is the feeling of consumers in the form of happy or disappointed, which occurs because it compares the product's expected performance (or results) to consumer expectations. While Tjiptono (2012) states that consumer satisfaction or discontent is the consumer's response to changes in the perceived discrepancy / disconfirmation between expectations and the actual performance of the product that is felt after using an item. Irawan (2012) believes there are 3 factors that can influence satisfaction, namely: (1) product quality, (2) price, and (3) service quality. A number of studies related to consumer satisfaction have been conducted by Rinala et al (2013), Radja et al (2013), Mulyana et al (2015), Husaeni (2016), Chandra et al (2018) Usman et al (2016), Zhang et al. (2016) Shahsavar et al (2017) whose results show that satisfaction affects loyalty.

\section{Loyalty.}

Loyalty according to Hurriyati (2015) play an important role in the company, maintaining them means increasing financial performance and maintaining business continuity. Loyalty is not seen only in terms of repeated transactions or purchases. Griffin (2015) said there are 4 characteristics of loyal customers, among others : (1) customers who regularly repurchase, (2) customers who buy other products / services at the same company, (3) customers who refer to goods / services to other people, and (4) customers who do not turn to other products, even if influenced by other competitors. While Tjiptono (2012) states that loyalty is a relationship between the company and customers where the creation of a 
satisfaction provides a good basis for repurchasing the same goods and forming a word of mouth recommendation. To become a loyal customer, the customer must go through several stages. Griffin (2015) states that there are several stages, namely: (1) suspects, (2) prospects, (3) disqualified prospects, (4) first time customers, (5) repeat customers, (6) clients, (7) ) advocates, and (8) partners.

\section{RESEARCH METHODS}

This research uses quantitative methods and by using the method of causal analysis. In addition, this research method uses a survey method. Population according to Sugiyono (2012) is a generalization area consisting of objects or subjects that have certain qualities and characteristics that are determined by researchers to be studied and then conclusions are drawn. The population used in this study were 1,130 students of SMK PGRI 35. Meanwhile, the sample is owned population which is part of the number and characteristics (Sugiyono, 2012). The determination of the sample size to be investigated in this research used Hair (2010) with a total sample of 160 respondents. The sampling method used in this research is incidental sampling, namely the technique of determining the number of samples based on coincidence, i.e. anyone who happens to meet can be used as a sample, if it is considered that the person who happened to be met is appropriate as a source of data. Data were collected using a questionnaire. Data analysis method using SEM - Lisrel.

\section{RESULTS AND DISCUSSION}

This study examines the unobserved indicators of loyalty. For validity tests that are processed in SEM all statements must have a Standardize Loading Factor (SLF) value> 0.7 to be considered valid. From the results of data processing, it can be seen that the service quality variable has an SLF value> 0.7 so that all indicators are declared valid. Likewise for the variables of school image, satisfaction, and loyalty which have a value of SLF $<0.7$, so that all indicators are declared valid. The next analysis is to test the reliability of all variables using the criteria for the value of $\mathrm{CR}>0.70$ and $\mathrm{VE}>0.5$, so that it can be concluded that all variables are declared reliable in this research. After the feasibility test of the data is carried out, the next step is to test the fit of the measurement model. The following are the results of the research model suitability test

Table 4. Research Model Fit Test Results

\begin{tabular}{|c|c|c|c|c|}
\hline \multirow{3}{*}{$\begin{array}{c}\text { Goodnes Of Fit Measures } \\
\text { Normed Chi-Square }\left(\chi^{2} / \mathrm{df}\right)\end{array}$} & \multicolumn{2}{|c|}{ Match Siza } & \multirow{2}{*}{\multicolumn{2}{|c|}{$\begin{array}{l}\text { Measurement } \\
\text { results }\end{array}$}} \\
\hline & \multirow{2}{*}{$\begin{array}{c}\text { Good Fit } \\
<2.0\end{array}$} & \multirow[t]{2}{*}{ Marginal Fit } & & \\
\hline & & & 1.297 & Fit \\
\hline $\mathrm{P}$ Value & $\begin{array}{c}0.05 \leq \mathrm{p} \leq \\
1.00\end{array}$ & $0.01 \leq \mathrm{p} \leq 0.05$ & 0.01 & $\begin{array}{l}\text { Marginal } \\
\text { Fit }\end{array}$ \\
\hline Root Mean Square Error (RMSEA) & $<0.08$ & & 0.043 & Fit \\
\hline Goodness of Fit Index (GFI) & $\geq 0.90$ & $0.80-<0.90$ & 0.82 & $\begin{array}{l}\text { Marginal } \\
\text { Fit }\end{array}$ \\
\hline $\begin{array}{l}\text { Adjusted Goodness of Fit Index } \\
\text { (AGFI) }\end{array}$ & $\geq 0.90$ & $0.70<0.90$ & 0.78 & $\begin{array}{l}\text { Marginal } \\
\text { Fit }\end{array}$ \\
\hline Normal Fit Index (NFI) & $\geq 0.90$ & $0.80-<0.90$ & 0.98 & Fit \\
\hline Non-Normed Fit Index (NNFI) & $\geq 0.90$ & $0.80-<0.90$ & 0.99 & Fit \\
\hline Comparative Fit Index (CFI) & $\geq 0.90$ & $0.80-<0.90$ & 0.99 & Fit \\
\hline
\end{tabular}




\begin{tabular}{lllll} 
Increamental Fit Index (IFI) & $\geq 0.90$ & $0.80-<0.90$ & 0.99 & Fit \\
Relative Fit Index (RFI) & $\geq 0.90$ & $0.80-<0.90$ & 0.98 & Fit \\
\hline
\end{tabular}

It can be seen in the table above that the measurement model test shows that the overall model suitability value has shown a fit value. Because the measurement model test has Good Fit and does not need to be modified, the analysis is continued to the structural model test, which results will be the same as the measurement model test in the table above.

After obtaining a structural model with a good Goodness of Fit, the next step is to test the hypothesis. In this study, there are 5 hypotheses as previously described and the significance of each variable relationship was tested. The significance value $(\alpha)$ used is 0.05 or $5 \%$ with a t value of $\geq 1.96$ (Wijanto, 2008). The estimated value of the causal relationship from the structural model tested and the results of hypothesis testing by looking at the $\mathrm{t}$ value in the relationship between variables and can be seen in the following table (t-value $\geq 1.96$ ) is as follows:

Table5. Hypothesis testing

\begin{tabular}{lcl}
\hline Hubungan Antar Konstruk & T-Values & Keterangan \\
\hline Service Quality-> Satisfaction & 3.84 & $\begin{array}{l}\text { Has a positive and } \\
\text { significant impact } \\
\text { Has a positive and } \\
\text { significant impact }\end{array}$ \\
School Image -> Satisfaction & 5.43 & $\begin{array}{l}\text { Has a positive and } \\
\text { significant impact }\end{array}$ \\
Service Quality-> Loyality & 2.28 & $\begin{array}{l}\text { Has a positive and } \\
\text { significant impact }\end{array}$ \\
School Image -> Loyality & 4.02 & $\begin{array}{l}\text { Has a positive and } \\
\text { significant impact }\end{array}$ \\
Satisfaction -> Loyality & 5.40 &
\end{tabular}

\section{DISCUSSION}

Service quality has a positive and significant impact on satisfaction, in other words, if the service quality of SMK PGRI 35 Jakarta has increased, it will affect satisfaction. The results of this research also confirm the results of research by Mestrovic (2017) regarding the effect of service quality on student satisfaction and behavioral intentions. School image has a positive and significant effect directly on satisfaction. In other words, if the image of the PGRI 35 Jakarta SMK school has increased, it will affect satisfaction. The results of this research also confirm the results of research by Khusaeni (2016) on the Relationship between Service Quality, School Image, Student Satisfaction and Student Loyalty. Service quality has a positive and significant effect directly on loyalty. In other words, if the service quality of SMK PGRI 35 Jakarta has increased, it will affect loyalty. The results of this study also confirm the results of research from Ali et al (2018) on the determinants of student loyalty. School image has a positive and significant effect directly on loyalty. In other words, if the image of the SMK PGRI 35 Jakarta school has increased, it will affect loyalty. Satisfaction 
has a positive and significant effect directly on loyalty. In other words, if the satisfaction of SMK PGRI 35 Jakarta has increased, it will increase loyalty.

The results of this research indicate that service quality and school image have a positive, significant, and strong influence on student satisfaction and loyalty at SMK PGRI 35 Jakarta. In an effort to increase student satisfaction and loyalty at SMK PGRI 35 Jakarta, schools must continue to improve service quality, including teachers who are always dressed neatly and have a professional attitude, clean and comfortable classes, disciplined KBM, always provide accurate information, responsive $\mathrm{BK}$ to student problems and provide solutions to student problems. Besides continuing to maintain the quality of service, the creation of a school image also greatly affects student satisfaction. Such as management that the public can trust, has a good name, is disciplined and punctual, and has a logo that is easy to remember. When the quality of service provided is not proportional to the benefits that customers get, student loyalty will not be created because students are no longer loyal to the services provided. This will affect the overall perceptions of students on the quality of services provided by the school, the image the school has built, and satisfaction with school management performance. If students' perceptions of these three variables are bad, then the school will be abandoned by the students and in the end the programs assigned by the government to serve students will also not be achieved.

\section{CONCLUSION}

\section{Conclusion}

a. The quality of services provided by the school has a positive and significant effect on student satisfaction by $37 \%$.

b. The school image that is built has a positive and significant influence on student satisfaction by $56 \%$.

c. Student satisfaction has a positive and significant impact on student loyalty by $47 \%$.

d. The school image that is built has a positive and significant influence on student loyalty by $36 \%$

e. The quality of service received by students directly has a positive and significant effect on student loyalty by $17 \%$.

f. The quality of service received by students provides a positive and significant impact on student loyalty through student satisfaction of $16 \%$.

g. The school image that is built directly has a positive and significant effect on student loyalty by $36.0 \%$.

$\mathrm{h}$. The school image that is built has a positive and significant influence on student loyalty through student satisfaction of $27.0 \%$.

i. It can be concluded that without going through the intervening variables, it will directly have a higher effect value than indirectly.

\section{Suggestions}

a. In terms of service quality, teachers must be more familiar with teaching materials and materials according to their respective fields. In addition to mastering teaching materials and materials, the professional competence of teachers must be continuously improved so that they can provide a pleasant learning experience and students do not become bored.

b. In terms of the image of the school, teachers and employees must be more concerned with what are the problems and needs of students. It is better if teachers and employees can continue to do their best in meeting the needs of students both in classroom learning and outside the classroom services. 
c. The contribution of education and development needs to be reviewed, it must be commensurate with the facilities that students get.

d. What is the advantage of the school compared to other schools continues to be improved, so that students do not hesitate to convey the advantages of their school to others.

\section{REFERENCES}

A. Parasuraman, V. A. (2011). A Conceptual Model of Service Quality and Its Implication forr Future Reaserch. Service Quality, 2015-220.

Alma, Buchari. (2009), Manajemen Bisnis Syariah. Bandung: Alfabeta.

Andreassen TW, Lindestad B. (1998), "Customer Loyalty and Complex Services: The Impact of Corporate Image on Quality, Customer Satisfaction and Loyalty for Customers with Varying Degrees of Service Expertise. International Journal of Service Industri Management, Vol. 9, No. 1, pp. 7-23.

NehmeAzoury, LindosDaou, Charbel ELKhoury, (2014) University image and its relationship to student satisfaction- case of the Middle Eastern private business schools, International Strategic Management Review Volume 2, Issue 1,

Anusorn Kunanusorn, Duangporn Puttawong (2015), The Mediating Effect Of Satisfaction On Student Loyality To Higher Education Institution, European Scientific Journal October /SPECIAL/ edition Vol.1

Jingxian Zhang, Junqi Wang, Sophia D.Min, Kenny K. Chen, Haiyan Huang (2016)"Influence of Curriculum Quality and Educational Service Quality on Student Experiences : A Case Study in Sport Management Programs”. Journal of Hospitality,Leisure,Sport\&TourismEducation Vol.18, pp 81-91.

Fajar, Laksana, (2008). Manajemen Pemasaran. Yogyakarta: Penerbit Graha Ilmu

Hidajahningtyas, Nurullah, Andi Sularso dan Imam Suroso, (2013) "Pengaruh Citra, Kualitas Layanan Dan Kepuasan Terhadap Loyalitas Pasien Di Poliklinik Eksekutif Rumah Sakit Daerah Dr. Soebandi Kabupaten Jember", Jurnal Ekonomi Akuntansi dan Manajemen (JEAM), Vol. 12. No. 1. Hal. 39 - 53.

Marilees,B \& Fry, M. (2002), Corporate Branding: A framework for E - Retaliers. Corporate Reputation Review Vol. 5.

Andy Mulyana dan Devi Ayuni. 2016. Hubungan Antara Kualitas Jasa, Citra Destinasi, Kepuasan Pengunjung dan Niat Mengunjungi Kembali Taman Wisata Air Terjun di Bogor. Jurnal Manjemen Indonesia, Vol 16, N0 3

Bala Haruna (2017), K.Kiranand MuzammilTahira, Modelling web-based library service quality and user loyalty in the context of a developing country, The ElectronicLibrary Vol.35No.3

Consuegra, D., Molina, A. \& Esteban, Á. (2007) 'An integrated model of price, satisfaction and loyalty: An empirical analysis in the service sector', Journal of Product and Brand Management, 16(7), pp. 459-468. doi: 10.1108/10610420710834913.

Departemen Pendidikan Nasional.2003. Undang-undang RI No.20 tahun 2003.Tentang Sistem Pendidikan Nasional.

Dunja Mestrovic (2016), The Impact Of Service Quality Students Satisfaction And The World Of Mouth : The Case Of The University Of Rijeka Departments, Croatia, Eternova 89 September

Engel, James F., dkk. (1995). Perilaku Konsumen. Edisi ke-6. Jakarta Barat: Binarupa Aksara Fahrurrozi, (2012) Strategi Pemasaran Jasa dalam Meningkatkan Citra Lembaga Pendidikan Islam, Semarang

Fandy Tjiptono dan Gregorius chandra. (2016). Service, Quality \& satisfaction. Yogyakarta. Andi 
Fandy Tjiptono. (2014). Pemasaran Jasa (Prinsip, Penerapan, Penelitian). Yogyakarta. Andi Fatmawati, I. (2004). Citra Rumah Sakit, Kepuasan dan Loyalitas Pelanggan Studi Pada Rumah Sakit PKU Yogakarta. Jurnal Utilitas, Vol. 12

Gramler dan Brown dalam Hasan Ali, (2008), Marketing, Medpress (anggota IKAPI), Yogyakarta

Griffin, Jill. (2015).Strategi Pemasaran: How to keep it, How to earn it. Lexiton Books. New York. Alih Bahasa: Dwi Kartini Yahya.

Hurriyati, Ratih. (2015). Bauran Pemasaran dan Loyalitas Konsumen, Bandung: Alfabetha

Irawan, H. (2012). Indonesian Customer Satisfaction: Membedah Strategi Kepuasan Pelanggan Merek Pemenang ICSA, PT Alex Media Komputindo, Jakarta.

Khusaini, Ahmad. (2016). "Analisis Kualitas Pelayanan Terhadap Kepuasan Konsumen di SPA Club Area Yogyakarta". Yogyakarta: Fakultas Ilmu Keolahragaan. Universitas Negeri Yogyakarta

Kotler dan G. Amstrong.(2013). Prinsip-prinsip Pemasaran. Jilid 1. Edisi 12. Jakarta. Erlangga.

Kotler dan G. Amstrong.(2013). Prinsip-prinsip Pemasaran. Jilid 1. Edisi 12. Jakarta. Erlangga.

Kriyantono, Rachmat. (2010). Teknik praktis riset komunikasi: disertai contoh praktis riset media, public relation, advertising, komunikasi organisaso, komunikasi pemasaran. Jakarta: Kencana

Lunarindiah Gatri. (2016). The Influence of Corporate Image, Service Quality, Perceived Value Toward Student Satisfaction and Student Lotalty. Jurnal Manajemen dan Pemasaran Jasa. Vol. 9 No. 2

Lupiyoadi, Rambat. (2013). Manajemen Pemasaran Jasa. Jakarta: Salemba Empat.

María-Jesús Martínez-Argüelles and Josep-Maria Batalla-Busquets (206), Perceived Service Quality and Student Loyalty in an Online University, International Review of Research in Open and Distributed Learning Volume 17, Number 4

Molola Bosede Ajoye Miss (2014), Information Systems user Satisfication : A Survey Of The Postgraduate School Portal, University Of Ibadan, Nigeria, Library Philosophy and Practice (e-journal).Paper 1192

Peter, J. Paul dan Jerry C. Olson. 2000. Consumer Behavior. Perilaku konsumen dan Strategi Pemasaran Jilid 2.Edisi 4. Jakarta: Erlangga

Radja, Noventris Ratnawati, dkk (2016), "Pengaruh Kualitas Layanan Terhadap Kepuasan Siswa dan Dampaknya Terhadap Loyalitas Siswa di SMK Kristen Salatiga",

Rinala, I Nyoman et al. (2013). "Pengaruh Kualitas Pelayanan Akademik Terhadap Kepuasan dan Loyalitas Mahasiswa Pada Sekolah Tinggi Pariwisata Nusa Dua Bali," eJournal Program Pascasarjana Universitas Pendidikan Ganesha Program Studi Administrasi Pendidikan

Ruslan, Rosady (2012), Manajemen Public Relations dan media Komunikasi: Konsepsi dan Aplikasi, Jakarta : PT. RajaGrafindo Persada

Sabarguna, BS. (2008). Quality Asurance pelayanan Rumah Sakit. Jakarta: Sagung seto.

Supranto, J. (2011). Pengukuran Tingkat Kepuasan Pelanggan Untuk Menaikkan Pangsa Pasar. Penerbit Rineka Cipta, Jakarta

Sutisna (2012), Perilaku Konsumen dan Komunikasi Pemasaran, Edisi kedua, Bandung : Remaja Rosdakarya

Suwandi, Imam Mulyana Dwi. (2011). Citra Perusahaan. Seri Manajemen Pemasaran, www.e-imam.uni.acc, (https://oeconomicus.files.wordpress. com/2007/07/citraperusahaan.pdf 
Syamsiah, N. (2009). Analisis Faktor-Faktor yang Mempengaruhi Nilai yang Dirasakan Pelanggan untuk Menciptakan Kepuasan Pelanggan di RSUP Dokter Kariadi Semarang. Universitas Diponegoro

Teddy Chandra, Priyono and Lukmanul Hakim. (2015). The Influence Location, Products, Promotions, Service With Respect to Consumer Behavior, Review of European Studies, Volume 7. No12.

Tina Shahsavar, Frantisek Sudzina (2017), Student satisfaction and loyalty in Denmark: Application of EPSI methodology, PLOS ONE https://doi.org/10.1371/journal.pone.

Tjiptono,Fandy. (2012). Pemasaran Jasa-Prinsip, Penerapan, dan Penelitian. Penerbit Andi. Yogyakarta.

Wantara, Pribanus. (2015). The Relationships among Service Quality, Customer Satisfaction, an Customer Loyalty in Library Services. International Journal of Economics and Financial Issues

Zeithaml, Valarie A., Mary Jo Bitner dan Dwayne D. Gremler. (2009). Services Marketing \pm Integrating Customer Focus Across The Firm (5th ed). New York: McGraw-Hill. 